\title{
Creating Competitive Advantages for Companies by Developing Strategic Human Resource Management in the Face of the Challenges of the Revolution 4.0
}

\author{
Kosasih \\ Universitas Sangga Buana, Bandung, Indonesia \\ Email: kosasih@usbypkp.ac.id
}

\begin{abstract}
Since the development of technology with the Internet of Thing and Artificial Intelligence or what we know as the 4.0 industrial revolution, the competition for each company is to survive and develop very fast. For this reason, every organization or company must be able to show a competitive advantage that distinguishes the company from others. One of the efforts to create this competitive advantage is to increase the human resources the company has. For this effort, the organization or company must be able to develop strategic human resource management. Therefore, the aim of this research is to describe the influence of the concept of corporate strategic human resource management that can affect competitive advantage. The method used is library research by processing literature related to this study using a qualitative approach. The research results obtained from the literature used show that both strategic human resource management is very influential for the company's competitive advantage. The implication of this research is expected to contribute in determining business strategy and policy through the theories of this research.
\end{abstract}

Keywords: Strategic Human Resource Management, Industrial Revolution 4.0, Competitive Advantage.

\section{A. INTRODUCTION}

Every company has a goal of realizing its growth and long-term survival. In the era of revolution 4.0 which is marked by a complex business environment marked by rapid advances in information technology, companies and organizations always face very basic problems or challenges, namely how to survive in the present, while being able to face future competition (Gretzel et al., 2006; Bennet \& Bennet, 2004). This has spurred every company to always be able to improve its performance. The efficiency of the company is often an indicator of the success of the company's operations. The purpose of performance measurement is to compare current achievements with the previous year or the achievements of competitors (Horovitz \& Thietart, 1982; Tangen, 2004). By knowing its performance, companies can make revisions to irrelevant policies so that future achievements will be better (Wood, 2010).

At the business level, every company, both private and state-owned, always strives to improve its dominant position in the business segments of goods and services has served. Business units are structured based on market segments served with distinct and independent characteristics. Wheelen \& Hunger (2012), and 
Thompson \& Strickland (2007) state that a business unit is treated as a unit with its responsibility and authority in developing strategy. The development of this strategy must integrate various functional activities so that each business's objectives are achieved and will increase the profit margins of production and sales.

Furthermore, Wheelen \& Hunger (2012), and Thompson \& Strickland (2007) state that companies optimize resource productivity to improve company performance at the functional level. This initiative is rendered by integrating the organizational operations of the organization with the skills of each exercise. These practical behaviors can be related to the supply chain structure. Value chain is a system used to build value for consumers. This value for customers can be a competitive advantage for the company in developing its business. At the same time, this is done for the international level if the company has businesses in various countries.

This increasingly competitive market rivalry involves an overview of all the forces that have an impact on the accomplishment of the aims of a business enterprise. Business orientation and human resource strategy also need to be changed with a view to gaining opportunities and preventing risks (Legnick-Hall, 2011). External strength such as; consumer domination, technological change, deregulation and social change of course pose new challenges as well as opportunities for the creativity of human resources. In this case, management needs to refocus on a strategic basis (strategic refocusing) on an ongoing basis to get opportunities and avoid threats caused by the turmoil of competition which is very difficult to control (Labola, 2019).

According to Rumelt (2003), competitive advantage is the advantage over competitors achieved by conveying greater demand to the consumer, lowering costs or offering more incentives consistent with higher pricing. According to Hoffman (2000), there are three ways that companies can get a competitive advantage, first, Cost Leadership, a set of integrative acts to manufacture and distribute goods/services at the lowest cost to rivals with features that are desirable to consumers. Second, the Differentiation Strategy is a series of integrative actions designed to produce and offer goods / services that are perceived by different customers in terms of importance and unique to them, and the third strategic focus is a set of integrative acts intended to generate and deliver goods/services that benefit them. Needs of certain competitive categories or sectors in certain geographical areas (special products for special segments, or for special markets).

Human resources as managers of a business organization must always be responsive to global competition which is always changing at any time by changing the scope of business, creating new network relationships, aiming to create competitive advantage. Strategic human resource management is needed to achieve competitive advantage which is a dynamic process that can be achieved through superior skills which include technical, managerial and operational capabilities 
(Farchan, 2018). Superior human resources allow the formation of this dimension of excellence. In brief, there are several things that need to be understood as sources of excellence, namely; superior skill, superior resources, superior control. This will form the superior position of the business organization because it is able to create superior customer value and lower costs (Harjanti, 2012).

Strategic human resource management is a connection between human resources and strategic goals and objectives to enhance corporate efficiency and establish an organizational culture that promotes creativity in accordance with changes in its environment, or in other words, is a pattern of distributing human resources from the intended planned activities. to give an organization the ability to achieve its goals. The end result of strategic human resource management, especially in business organizations, is the ability to continuously increase or maintain customer satisfaction and loyalty, market share and high profit (Tampubolon, 2016).

Human resources are the decision makers in the aspects of finance, marketing, operations, and the use of technology in production. Strategic human resource management explores the consequences of the organizational approach on all human resource processes in the enterprise by converting business strategies into relevant human resource management systems (Sunarsi, 2018). The success of human resource management is largely determined by clear support for the organization's mission and strategy. Edwards et al (1997) stated that in this globalization era every organization must formulate its strategy in a global context. Currently, it is very important to understand human resources in the face of global competition. Good organizational / company management must know exactly how productivity can be increased. Increased productivity comes from the HR group who are challenged, empowered, have high enthusiasm to gain competitive advantage.

On the basis of the above definition, the authors are interested in carrying out research on the effect of competitive advantage with strategic human resource management by describing it theoretically based on the related literature and researched in this study.

\section{B. METHOD}

The research tool used in this article is the compilation of literature for library research related to the object of the problem being studied using a qualitative approach. According to Zed (2004), Library analysis is a research that uses techniques to collect material details by inserting existing facilities in the library, such as books, journals, records, story notes. Or pure library analysis relevant to the research object. Meanwhile, Khatibah (2011) suggests library research as an activity carried out systematically to collect, process, and conclude data using certain methods/techniques in order to find answers to problems faced through library research.

This research also takes a holistic approach to finding the issues under study. According to Moleong (2005), qualitative analysis is intended to explain the phenomenon encountered by research subjects such as actions, cognition, 
motivation, response, etc. Holistic, and by means of definitions in the form of vocabulary and phrases, natural in a special sense and using different natural approaches. Qualitative analysis is a research that is used to analyze, find, define and clarify the content or characteristics of social forces that cannot be explained, measured or represented using a quantitative approach (Saryono, 2010).

\section{RESULT AND DISCUSSION}

The term Strategic Human Resources refers to a specific set of HR management actions that a company encourages to achieve its goals. The most important objective of the HR strategy is to build committed employees especially in an environment without a union, this goal, including using a variety of methods for creating two-way connectivity, screening prospective employers that have ideals that are not human-oriented; making assurances for the most equal care possible; and safety for all employees; and take advantage of various promotions in various activities and provide opportunities for employees to fully realize their potential (Sheehan, 2005).

Cascio (2015) states all activities that influence individual behavior In their attempts to develop and execute the company's business needs. Wrihgt et al. (2005), describe an approach to making decisions on organizational schemes and plans related to employment relationships and policies and the implementation of recruitment, training, development, performance management, rewards and employee relations. Sakban et al. (2019) consists of planning, analysis and job classification, recruitment, selection and placement, job evaluation and compensation, work motivation and training and development.

Based on the above definition, It can be argued that strategic human resource management is the creation of a holistic strategy from a range of aspects by linking management of human capital and specific goals to enhance operational efficiency. In other words, it is an approach that explains the relationship between human resource management and strategic management in the company as a whole, both with regard to work, policies and implementation of recruitment, training, development, performance management, rewards and relationships with employees in order to achieve organizational goals.

Rapid business changes will change the map of business competition in the industry. These changes often cannot be responded to quickly by organizations due to various reasons including competency factors (knowledge, abilities, existing human resources expertise. Problems often faced by business organizations in developing and implementing business strategies in general are the unavailability of human resources who have sufficient competence and High motivation to carry out business strategies successfully (Ardiana et al., 2010). From several cases that have occurred in several companies, it shows that HR strategies that are not isolated to the business strategy being carried out open up greater opportunities for companies to succeed in overcoming their business problems. The problems faced in strategy implementation are of course not only related to the ability and motivation of human 
resources, but there are still many other factors that influence such as task design, structure, compensation systems, etc. The strategies implemented by the company vary. Based on the organizational level, there are three types of planning: organizational strategy, company strategy and practical strategy. The corporate strategy is structured as a long-term direction for the entire company, namely companies that have multiple business activities or multiple products (multi business enterprise). A business strategy is a strategy formulated by the activities of a corporate business unit (single business unit). Functional strategy is a strategy at the level of specific operational activities such as HR strategy, marketing strategy and so on.

Basically, the formulation of HR strategies is related to the process of formulating business strategies in the context of achieving strategic goals. Therefore, before reaching the formulation of HR strategies, to help explain the existence of HR initiatives in the sense of strategic goals, it is necessary to first explain the framework for the relationship between people and business needs and the direction of organizational strategy. Based on this framework, the HR strategy is elaborated from the organization's strategic plan, there are two phases of the strategic management process in relation to business strategy, namely: (a) strategy formulation includes environmental assessment and strategy development and (b) strategy implementation and evaluation. The process of strategy formulation as strategic planning includes several systematic activities: (a) Determining the strategic direction, including the vision, mission, and values developed in the organization. Vision shows where the organization will be taken, as a source of inspiration and motivation that has certain intrinsic values, therefore the vision must be realistic. Mission, is the foundation of the organization's existence contained in the form of a statement showing what the organization was founded for. Vision and mission require the support of certain values which are then translated into objectives in the strategic management process; (b) Identification of the environment and SWOT analysis, namely the factors of the business environment that are relevant to the current condition of the company and conduct a SWOT analysis. Managers who are involved in planning, also need to identify other factors including competence and competitive advantage to assess the role of the company in the industry; (c) Formulating strategic objectives. In this phase, the formulation of the vision, mission and objectives is translated into strategic objectives at the corporate level, then formulates strategic goals at the functional level; (d) Developing alternative strategies. The business strategy is related to the mission and objectives it carries. HR strategy to provide qualified human resources is expected to be able to support the implementation of certain business strategies in order to achieve the mission and objectives outlined; (e) Choosing a strategy. To reduce the possibility of bias in the concept of intended strategy, lower-level managers are involved in the process of formulating a strategy that is fundamentally developed from experiences which they call the emergent strategy. 
The next phase is strategy implementation and evaluation, taking into account several factors, namely: (1) Task design. Tasks need to be redesigned so that individual and group work performance can be improved; (2) Organizational structure. Whether the organizational structure is line or functional (lateral), it is necessary to consider whether it should change when there is a change in business strategy; (3) System. Is a set of rules that cause business processes to run. Therefore, decision-making mechanisms, performance appraisal systems, and so on must be able to encourage employee work dynamics; (4) Process. This variable needs to be considered so that the service process from start to finish is guaranteed its effectiveness and efficiency; (5) Technology. Technological factors play an important role in improving information systems in organizations. The service system will be more effective through the application of technology; (6) The compensation system must be able to increase employee motivation. organizational demands culminate in what rewards can be given by the organization for the achievements they contribute; (7) Training and development. Training, education and development programs must be able to improve the skills and abilities of employees and help optimize their potential.

In practice, it is not easy to realize the concept of strategy in the daily behavior of employees in their positions. There are several factors that have the potential to become obstacles, namely: (a) weak leadership; (b) the organization's internal communication process is less effective; and (c) low individual learning capacity.

The HR strategy defines the value created by the HRM function and determines how the work done by the HR manager together with other line managers adds value to the business being run. HR strategy thus determines what HR activities, priorities, are needed to create that value. Aldin (2005) states that there is an understanding of the relationship between strategy and effective $H R$ management. Aldin (2005), recognizes that organization, organizational culture, capabilities are important sources of competitive advantage.

HR strategies in various forms can be seen in the HR function being carried out. Sonnenfeld \& Peiperl (1988) suggest that there are four typologies of HR strategies, especially regarding career systems, which include: a) Club, a company that uses a low cost strategy that focuses its orientation on cost controlling. Companies of this type compete through increased cost efficiency, quality maintenance, and customer service, for example airlines, banks. HR policies in this type emphasize the training and development ( $T$ and $D$ ) activities of employees as an effort to optimize their performance and the company strives for low labor turnover and employees will work in the long term; b) Baseball Team. In this type, companies generally carry out innovation strategies, namely strategies that always prioritize the creation of new products and are willing to take risks. Creativity is highly valued. The approach in fulfilling HR needs in this company tends to be a "buy" approach. Competition among the more talented individuals has a low commitment, a high level of labor turnover; c) Academy. Companies that fall into this type of category include companies manufacturing electronic goods, 
pharmaceutical manufacturers, automotives and so on. Preusan strategy orientation generally prioritizes innovation and seeks to exploit the right position in the competitive market. The HR strategy that is implemented lies between the club type strategy and the baseball team. In this category, human resources development is substantially carried out, but it is often taken from outside sources as a way to meet the needs of vacant top positions; d) Fortress. Companies in this type are always at a high level of market competition so that the strategy orientation that is carried out tends to be reactive. HR policies tend to carry out a retrenchement strategy (reduction) and only retain certain individuals who are the main supporters of the company's functions.

To win a competitive advantage in the market has grown rapidly day by day and radically created complexity in various businesses. The area of human resource management has evolved in line with the strategic management market in recent years. The results of Brewster's (1999) research suggest that to achieve competitive advantage, every business unit in a diversified company must adjust its human resource policies to the market conditions of its respective products. In doing so, Human Resources Professionals work with a Strategic Partner approach, in order to achieve confidence in optimizing business strategies. Therefore, operationalizing the strategy is the key to achieving business goals through professional human resources.

Human resource management strategy results in employee behaviors that focus on key business priorities, which in turn will generate profit, growth and increase market value. Much attention has been paid to human resource management from various perspectives within the organization which has not yet yielded maximum results. One of the main causes is in identifying the differences between human resource management and strategic human resource management. In other words, making human resource management strategies more strategic than human resource management (Mangkuprawira, 2003).

With regard to the strategic impact of human resource management and competitive advantage, the company will operate with a high level of product innovation, high product quality, and careful management of production costs. Therefore human resource management activities will include making selections for the creation of high individual employee skills; provide clearer rules; using minimal costs; make major investments in human resources; provide more experience to employees; give rewards; and reward performance for long-term implications. It cannot be denied that the existence of human resource management is to develop organizational effectiveness. In other words, the existence of an organization is to optimize the role of human resources in achieving organizational goals. As stated by Mangkuprawira (2003) that human resource activities are actions taken to provide and maintain a high-performing workforce within the company.

In essence, the role of human capital in gaining a competitive edge cannot be overlooked. This is because human resources have a very strategic role in the formulation of goals, formulation of strategies, and implementation of organizational 
strategies. In addition, the company also has a role in the field of personnel and industrial relations. In order to accomplish well the corporate priorities, the role of strategic human resource management needs to be well conceived. In accordance with the opinion of Armstrong (2003), the role of strategic human resource management is implemented in various activities including: strategic planning; strategic withdrawal and selection of human resources; strategic training and human resource development; strategic job appraisal; strategic compensation; and strategic management and employee relations. All these strategic aspects need to be formulated appropriately so that the goals of the organization's strategy can be realized.

\section{CONCLUSION}

Strategic human resource management has an impact on competitive advantage simultaneously. The strategic human resource management point of view considers employees as strategic resources and treating people as an important investment for company performance. Human resource management strategy results in employee behaviors that focus on key business priorities, which in turn will generate profit, growth and increase market value.

The role of strategic human resource management is implemented in various activities including: strategic planning; strategic withdrawal and selection of human resources; strategic training and human resource development; strategic job appraisal; strategic compensation; and strategic management and employee relations. All these strategic aspects need to be formulated appropriately so that the goals of the organization's strategy can be realized.

\section{REFERENCES}

1. Aldi, B. E. (2005). Menjadikan Manajemen Pengetahuan sebagai Keunggulan Kompetitif Perusahaan melalui Strategi Berbasis Pengetahuan. Jurnal Studi Manajemen dan Organisasi (JSMO), 2(1), 58-68.

2. Amstrong, M. (2003). Manajemen Sumber Daya Manusia Stratejik. Jakarta: Gramedia.

3. Ardiana, I. D. K. R., Brahmayanti, I. A., \& Subaedi, S. (2010). Kompetensi SDM UKM dan Pengaruhnya Terhadap Kinerja UKM di Surabaya. Jurnal Manajemen dan Kewirausahaan, 12(1), 42-55.

4. Bennet, A., \& Bennet, D. (2004). Organizational Survivali in the New World. UK: Routledge.

5. Brewster, C. (1999). Strategic Human Resource Management: The Value of Different Paradigms. Management International Review (pp. 45-64). Gabler Verlag, Wiesbaden.

6. Cascio, W. F. (2015). Managing Human Resources. New York: McGraw-Hill.

7. Edwards, J. E., Thomas, M. D., Rosenfeld, P., \& Booth-Kewley, S. (1997). How to Conduct Organizational Surveys: A Step-By-Step Guide. Sage. 
8. Farchan, F. (2018). Strategi MSDM Sebuah Cara Menciptakan Kinerja Organisasi Dalam Mencapai Keunggulan Bersaing. Risâlah, Jurnal Pendidikan dan Studi Islam, 4(1), 42-52.

9. Gretzel, U., Fesenmaier, D. R., Formica, S., \& O'Leary, J. T. (2006). Searching for the Future: Challenges Faced by Destination Marketing Organizations. Journal of Travel Research, 45(2), 116-126.

10. Harjanti, S. (2012). Menciptakan Keunggulan Bersaing yang Berkelanjutan Melalui Manajemen Sumber Daya Manusia.Jurnal Ekonomi dan Kewirausahaan, 4(1).

11. Hoffman, N. P. (2000). An Examination of the "Sustainable Competitive Advantage" Concept: Past, Present, and Future. Academy of Marketing Science Review, 4(2000), 1-16.

12. Horovitz, J. H., \& Thiétart, R. A. (1982). Strategy, Management Design and Firm Performance. Strategic Management Journal, 67-76.

13. Khatibah, K. (2011). Penelitian kepustakaan. Iqra': Jurnal Perpustakaan dan Informasi, 5(01), 36-39.

14. Labola, Y. A. (2019). Konsep Pengembangan Sumber Daya Manusia Berbasis Kompetensi, Bakat dan Ketahanan dalam Organisasi. Jurnal Manajemen $\mathcal{E}$ Kewirausahaan, 7(1), 28-35.

15. Lengnick-Hall, C. A., Beck, T. E., \& Lengnick-Hall, M. L. (2011). Developing A Capacity for Organizational Resilience Through Strategic Human Resource Management. Human Resource Management Review, 21(3), 243-255.

16. Mangkuprawira, T. (2003). Manajemen Sumber Daya Manusia Strategik. Yogyakarta: UGM.

17. Moleong, L. J. (2005). Metodologi Penelitian Kualitatif. Bandung: Remaja Rosdakarya

18. Rumelt, R. P. (2003). What in The World is Competitive Advantage. Policy Working Paper, 105(2003), 1-5.

19. Sakban, S., Nurmal, I., \& Ridwan, R. B. (2019). Manajemen Sumber Daya Manusia. Alignment: Journal of Administration and Educational Management, 2(1), 93-104.

20. Saryono, A. (2010). Metodologi Penelitian Kualitatif Dalam Bidang Kesehatan. Yogyakarta: Nuha Medika.

21. Sheehan, C. (2005). A Model for HRM Strategic Integration. Personnel Review.

22. Sonnenfeld, J. A., \& Peiperl, M. A. (1988). Staffing Policy as a Strategic Response: A Typology Of Career Systems. Academy of Management Review, 13(4), 588-600.

23. Sunarsi, D. (2018). Pengembangan Sumber Daya Manusia Strategik \& Karakterisrik Sistem Pendukungnya: Sebuah Tinjauan. Jurnal Ilmiah MEA (Manajemen, Ekonomi, E Akuntansi), 2(3), 178-194.

24. Tampubolon, H. (2016). Strategi Manajemen Sumber Daya Manusia Dan Perannya Dalam Pengembangan Keunggulan Bersaing. Depok: Papas Sinar Sinanti. 
25. Tangen, S. (2004). Performance Measurement: from Philosophy to Practice. International Journal of Productivity and Performance Management.

26. Thompson, Jr. A. A., Strickland III, A. J., \& Gamble, J. E. (2007). Crafting and Executing Strategy: The Quest for Competitive Advantage Concepts and Cases. New York: Mc Graw-Hill Company, Inc.

27. Ulrich, D. (1997). Human Resource Champions. USA: Harvard Business School Press.

28. Wheelen, T. L., \& Hunger, J. D. (2012). Strategic Management and Business Policy: Achieving Sustainability, 13th Edition. New Jersey: Pearson Education, Inc.

29. Wood, D. J. (2010). Measuring Corporate Social Performance: A Review. International Journal of Management Reviews, 12(1), 50-84.

30. Wright, P. M., Snell, S. A., \& Dyer, L. (2005). New models of Strategic HRM in A Global Context. The International Journal of Human Resource Management, 16(6), 875-881.

31. Zed, M. (2004). Metode Peneletian Kepustakaan. Jakarta: Yayasan Obor Indonesia. 